\title{
MUNICIPAL WASTEWATER CONCENTRATIONS OF PHARMACEUTICAL AND XENO- ESTROGENS: WILDLIFE AND HUMAN HEALTH IMPLICATIONS
}

\author{
Maxine Wright-Walters ${ }^{1}$, MSc., and Conrad Volz ${ }^{1,2,3}$, Dr.PH, MPH, (1) University of Pittsburgh, \\ Graduate School of Public Health, Department of Environmental and Occupational Health, Pittsburgh \\ PA., USA, (2) University of Pittsburgh Cancer Institute, Center for Environmental Oncology, Co-Director \\ Exposure Assessment, Pittsburgh, PA, USA, (3) Scientific Director, Center for Healthy Environments \\ and Communities, Pittsburgh, USA.
}

ABSTRACT: Most pharmaceutical estrogens and xenoestrogens are introduced into the environment through municipal waste water treatment plant (WWTP) effluent sources. These effluents contain synthetic compounds; surfactants, flame retardants and halogenated hydrocarbons that can mimic estrogens; and are discharged directly into rivers and lakes. As rivers and lakes are used for water and food supply, and recreation, and wastewater effluent usage increases, the presence and concentration of xenoestrogens in surface water becomes a valid public health concern. Additionally, many USA cities have significant combined sewer overflows releasing untreated sewage directly into surface waters, thus increasing the amounts of xenoestrogens finding their way into drinking water supplies and commercial and subsistence fishing habitat.

In the United States, humans are exposed daily to both pharmaceutical and xenoestrogens which have been implicated in various human health outcomes, such as testicular dysgenesis syndrome including testicular cancer and breast cancer in women. Also, they can have adverse reproductive effects in aquatic wildlife through sex reversals, production of intersex individuals, alterations in mating, and prevention of gonadal maturation. Combinations of estrogenic compounds are present in municipal WWTP effluents but, the natural estrogens, 17 $\beta$-estradiol (E2) and estrone (E1), and the synthetic E2 derivate $17 \alpha$-ethinylestradiol (EE2) are most responsible for in vitro estrogenic activity. Each xenoestrogen exhibits its own wildlife or human health risk, but synergistic effects could occur with xenoestrogen mixtures. Less than $1 \mathrm{ng} / \mathrm{L}$ EE2 can cause feminization of male fishes, $4 \mathrm{ng} / \mathrm{L}$ caused abnormal reproductive development (male fathead minnows). E2 has been detected at concentrations from $1 \mathrm{ng} / \mathrm{L}$ to $80 \mathrm{ng} / \mathrm{L}$. Total estrogenicity (E2 equivalents) of $147 \mathrm{ng} / \mathrm{L}$ has been measured in WWTP effluent. Nonylphenol, a surfactant and brominated biphenyls, a flame retardant have been detected between $0.1-3.7 \mu \mathrm{g} / \mathrm{L}$ and $0.3-4.6 \mathrm{mg} / \mathrm{kg}$ (on suspended particles) respectively.

Understanding the species and xenoestrogen concentrations in surface water is imperative for environmental public health tracking of associated disease states. Such research will determine the necessity for utilizing limited and competing public financial resources to invest in technology to remove xenoestrogens from surface waters and, in regulation of fish or wildlife consumption from our rivers and lakes.

\section{INTRODUCTION}

Most pharmaceutical estrogens and xenoestrogens are introduced directly into surface waters through municipal wastewater treatment plant (WWTP) effluent sources, also called sewage treatment works (STW) (Daughton 1999; Norris 2007). The low concentrations of individual pharmaceutical estrogens (possibly exceeding the catabolic enzyme affinities of sewage microbiota), coupled with their metabolic "novelty," leads to incomplete removal from STWs (Daughton 1999). Municipal wastewaters are a complex mixture containing estrogens and estrogen mimics called xenoestrogens, (Kidd, Blanchfield 
et al. 2007) natural and synthetic xenobiotics, household and agricultural chemicals, pharmaceuticals, hormones, and other compounds, many of which remain unidentified (Stevens JL 2003). The majority of natural and pharmaceutical estrogens excreted by humans as well as xenoestrogens from numerous domestic and municipal sources (e.g., detergents, plastics, cosmetics,) enter WWTPs (Norris 2007). STWs receiving domestic and pharmaceutical waste release a complex (and ill-defined) mixture of natural and synthetic chemicals into the aquatic environment, due to their partial or complete resistance to biodegradation during the treatment process (Desbrow and Waldock 1998). Most of these compounds are retained in biosolids and a smaller portion typically appears in the wastewater effluent depending on the chemical and the type of treatment and retention times. Currently, more than half of the biosolids produced by municipal wastewater treatment systems is applied to land as a soil conditioner or fertilizer and the remaining solids are incinerated or landfilled (USEPA 2004; King, Ballereau et al. 2006). These disposal practices provide numerous routes for xenoestrogen reentry into environmental media and ultimately surface water. The use of biosolids as a soil conditioner and fertilizer allows for pharmaceutical estrogens and xenoestrogens exposure through the food supply chain and also reentry into surface water systems through run off, and contaminated groundwater outflow. Through incineration, compounds such as dioxins and furans are released into the air and may be deposited in watersheds through wet and dry deposition. Thus, there are many routes of reentry of xenoestrogens in and attached to the surface of biosolids from WWTPs, thus possibly, increasing their environmental concentration and exposure routes for both humans and animals. There are over 16,000 municipal WWTPs nationwide and over $75 \%$ of the nation's population is being served by centralized wastewater collection and treatment systems. The remaining population uses septic or other onsite systems. (USEPA 2004), which have not been adequately studied for xenoestrogens release but, due to their high failure rate and lack of maintenance, could be considered potential non-point releasers of estrogenic compounds. Therefore, there can be an extremely varied mixture of pharmaceutical estrogens and xenoestrogens reentering surface waters possibly contaminating municipal drinking water supplies. But, what are the environmental concentrations of these compounds and are these concentrations significant enough to cause harm to human and wildlife health. Is human pharmaceutical estrogen and xenoestrogen exposure a valid public health concern?

\section{THE PROBLEM}

In the United States humans are exposed daily to xenoestrogens in food (e.g., phytoestrogens, various pesticides) and from contact with detergents [e.g., nonylphenols (NP)] and ingestion of plastic additives from plastic bottles, metal beverage can linings and food packaging (e.g., phthalates, bisphenol A (BPA), NP). Health care contributes estrogenic chemicals through pharmaceuticals and plastics used for surgical tubing and gloves. In addition, many personal care products (e.g., shampoos, cosmetics, aftershave lotions) contain xenoestrogens such as phthalates, NP and BPA. Most of these pharmaceutical and xenoestrogens are introduced into the environment via municipal WWTPs. Treated WWTP effluents are directly discharged in rivers and lakes. A recent publication by the U.S. Geological Survey reported that reproductive hormones and estrogenic alkylphenols were present in $40 \%$ and $70 \%$, respectively, of the surveyed U.S. surface waters (USEPA 2001). Thus, as rivers and lakes are used for municipal water sources, to help produce our food supply and for recreation, and as wastewater effluent water reuse increases, the presence and concentration of xenoestrogens in surface water becomes a valid public health concern. Advances in civilization coupled with rising population levels have resulted in an increasing need to treat and recycle available water resources. In the United States surface water provides for $62 \%$ of the public water drinking supply (University of Michigan 2005). Irrigation remains the largest use of freshwater in the United States and totaled $137 \mathrm{Bgal} / \mathrm{d}$ for 2000. Since 1950, irrigation has accounted for about $65 \%$ of total water withdrawals, excluding those for thermoelectric power. Historically, more surface water than ground water has been used for irrigation (Hutson Susan S. 2004). Following use, water is returned to the aquatic environment, usually via STWs of varying processes and performance, which improves its quality, but it has a high probability of being withdrawn downstream for municipal or 
industrial reuse. In US cities with a high population density, the volume of effluent discharged from STWs can be considerable, sometimes contributing up to $50 \%$ of the flow of a river, a figure that can rise as high as $90 \%$ in periods of low rainfall (Routledge, Sheahan et al. 1998).

STWs permanently receive a complex mixture of industrial, domestic, and agricultural wastewater containing a load of synthetic and natural chemical compounds. It has been demonstrated that, because of incomplete removal or conversion to an active form during the process of sewage treatment, pharmaceutical estrogens and xenoestrogens are released into surface water like rivers, lakes, and seas or adsorbed to sewage sludge or sediment (Liney, Hagger et al. 2006). These chemicals are found in low parts per trillion in the aquatic environment (Ternes, Kreckel et al. 1999).

\section{IMPACT ON THE POPULATION}

Both pharmaceutical estrogens and xenoestrogens have been implicated in various human health outcomes, such as testicular dysgenesis syndrome including testicular cancer and breast cancer in women (Giwercman 1993; Carlsen 1995; Toppari 1996). Also, they can have adverse reproductive effects in aquatic wildlife through sex reversals, production of intersex individuals, alterations in mating, and prevention of gonadal maturation.

Human Effects. Xenoestrogens have been implicated in a variety of medical problems. Foremost is the concern that xenoestrogens as false messengers disrupt the process of reproduction. Reproductive issues, which are of concerns in humans, are fetal exposure (perhaps leading to hypospadias) and decreased reproductive ability in men (i.e. decrease in sperm numbers and abnormal sperm shapes) and testicular carcinoma in situ. Another issue is the potential effect of xenoestrogens on oncogenes, specifically, it is implicated in breast cancer in women (Giwercman 1993; Carlsen 1995; Toppari 1996; Körner and Hagenmaier 2001), endometriosis (Adlercreutz 1995 ), heart disease (Meyer 2001), osteoporosis (Meyer 2001) and Alzheimer's disease (Meyer 2001). It is important to note that a recent comprehensive literature survey of 48 endocrine disrupting chemicals (EDCs) revealed that $79 \%$ of these EDCs were also carcinogenic or mutagenic, 52\% were also immunotoxic, and 50\% were also neurotoxic (Choi SM 2004). Both 4-tert-nonylphenol (4-NP) and BPA, for example, are contaminants found at appreciable concentrations in the aquatic environment that can cause endocrine disruption by interacting with both the estrogen receptor as agonists (Gaido KW 1997) and the androgen receptor (Sohoni 1998). In addition, 4NP can disrupt steroidogenesis in the liver and can interfere with the dynamic control of folliclestimulating hormone release from the pituitary (Harris CA 2001).

Wildlife Effects. Assessing whether any pharmaceutical estrogens or xenoestrogens pose a threat to the natural environment requires balancing information on its potency against observed environmental concentrations (Colborn T 1993). In many instances it is difficult to assign causality because of the complexity of environmental contaminants and the lack of analytical data that document contaminant levels during critical windows of exposure (Safe 2000). Nevertheless, there have been several incidents in wildlife populations that strongly correlate with exposure to specific industrial chemicals; this includes altered sex determination in alligators in Lake Apopka, Florida, exposed to a spill of organochlorine pesticides from a chemical waste site (Guillette LJ Jr 1994; Guillette LJ Jr 1995; Guillette LJ Jr 1996). Several studies on wildlife populations have documented adverse effects that correlate with exposure to one or more putative endocrine-disrupting chemicals (Giesy JP 1994; Sumpter and Jobling 1995; Jobling 2003). Reproductive abnormalities have been observed in several wildlife populations living in polluted areas. (Guillette LJ Jr 1994; Guillette LJ Jr 1995; Guillette LJ Jr 1996; Jobling S 1998).

There is considerable evidence that fishes inhabiting waters that receive untreated municipal wastewaters or effluents from municipal WWTPs are exposed to chemicals that affect reproductive endocrine function (Kidd, Blanchfield et al. 2007). Estrogenic effects of treated wastewater, released into the aquatic environment, were first verified by Purdom et al., in 1994 (Purdom 1994). Purdom and 
colleagues reported that STW effluent was estrogenic to fish, causing feminization. The STW effluents tested were mainly domestic (rather than industrial) in source, indicating that the estrogenic component(s) were likely to be domestic in origin and were probably common to most STWs (Desbrow and Waldock 1998). Male fishes downstream of some wastewater outfalls produce vitellogenin (VTG) (a protein normally synthesized by females during oocyte maturation) and early-stage eggs in their testes, and this feminization has been attributed to the presence of estrogenic substances such as natural estrogens [ $17 \beta$ estradiol (E2), the synthetic estrogen used in birth-control pills 17 $\alpha$-ethinylestradiol (EE2), or weaker estrogen mimics such as NP in the water (Kidd, Blanchfield et al. 2007). Recent studies have also shown that concentrations of 4-NP and BPA that inhibit gonadal development and reproductive function in fish can also cause damage to the kidneys (as a consequence of VTG induction), and decreased body weight and induce stressed behavior (Magliulo L 2002). DNA damage in barnacles has also been reported (Atienzar FA 2002). Similarly, steroid estrogens that are known to be present in WWTP effluents (Desbrow and Waldock 1998) and to cause feminizing effects in fish have been reported to be genotoxic in mammals both in cell lines and in vivo (Nutter LM 1991; Banerjee SK 1994; Han XL 1994; Nutter LM 1994 ). In laboratory studies, it has been confirmed that environmental contaminants with endocrine disrupting properties (EDCs) can disturb the development and expression of sexual characteristics in fish (Gimeno et al. 1996; Gray and Metcalfe 1997), amphibians (Hayes TB 2002), reptiles (Crain DA 1999; Willingham 1999), birds (Feyk LA 1998), and mammals (Gray LE 1994; Sharpe, Fisher et al. 1995). However, the extent to which the sexual characteristics and reproductive capabilities of natural populations are impacted by these EDCs is still not well understood.

\section{SOURCE OF THE PROBLEM}

Municipal Wastewater Treatment Plants and the Clean Water Act. Potable water utilities select a treatment train that is most appropriate for the contaminants found in their source water. The most commonly used processes include flocculation, sedimentation, filtration, and disinfection for surface water. Some treatment trains also include ion exchange and adsorption techniques (USEPA 2001). These conventional processes, according to the EPA are inefficient for substantially reducing certain pesticide concentrations and other EDCs including pharmaceutical and xenoestrogens from source water (USEPA 2001). Additionally, the Clean Water Act, amended in 1972 which addresses WWTP releases and the Safe Drinking Water Act (SDWA), first enacted in 1974 and amended in 1986 and 1996, which regulates contaminants in public water supplies does not have any provisions for removal or testing of xenoestrogens or pharmaceutical estrogens. Furthermore, many USA cities such as Pittsburgh and Los Angeles have significant combined sewer overflows releasing untreated sewage directly into surface waters, thus increasing the amounts and concentrations of xenoestrogens finding their way into drinking water supplies and commercial and subsistence fishing habitat. Many of the earliest sewer systems were combined sewers, designed to collect both sanitary wastewater and storm water runoff in a single system. These combined sewer systems were designed to provide storm drainage from streets and roofs to prevent flooding in cities. Later, lines were added to carry domestic wastewater away from homes and businesses. Early sanitarians thought that these combined systems provided adequate health protection. We now know that the overflows designed to release excess flow during rains also release pathogens and other pollutants (USEPA 2004).

\section{CONCENTRATIONS IN THE ENVIRONMENT}

Steroid estrogens have the potential to exert estrogenic effects in the low ng/L level, whereas alkylphenolic compounds are estrogenic at $\mu \mathrm{g} / \mathrm{L}$ concentrations (Routledge, Sheahan et al. 1998). Natural and synthetic hormones are frequently detected in STW effluents and receiving surface waters with concentrations ranging from pg/L to ng/ L (Belfroid 1999; Baronti 2000; Kuch and Ballschmiter 2001), whereas alkylphenolic compounds are found in concentrations up to $\mu \mathrm{g} / \mathrm{L}$ (Bolz, Hagenmaier et al. 2001; Stachel, Ehrhorn et al. 2003; Jin, Huang et al. 2004). 
Ternes et al., (Ternes, Bonerz et al. 2007) were able to show in aerobic batch experiments that steroid conjugates such as glucuronides of E2 are rapidly cleaved in contact with activated sludge, and thus the active form of the estrogen is released. To date, estrogenic effects on aquatic wildlife have not been conclusively linked to only one particular compound, but some chemicals are mainly responsible for higher estrogenicity indexes. Among them, the natural estrogens estrone (E1) and E2, and the exogenous, EE2, the active ingredient in oral contraceptive pills, possess the highest estrogenicity indexes. Apart from these steroids, alkylphenols such as 4-tert-octylphenol and the technical isomer mixture of 4-NP, both breakdown products of nonionic surfactants (Desbrow and Waldock 1998), and BPA, a widely used monomer for epoxy resins, show estrogenic potentials of approximately 4 orders of magnitude lower than E2 (Ternes, Kreckel et al. 1999). Also representatives of the groups of PCBs, dioxins, phytoestrogens, pesticides, preservatives, antioxidants, or phthalic esters contribute to the daily exogenous burden of humans and wildlife with hormonally active agents (Belfroid 1999; Larsson 1999 ; Thorpe KL 2003; Zhou 2007).

Due to their incomplete breakdown in current municipal WWTP processes (Ternes, Kreckel et al. 1999), natural and synthetic estrogens can be found in the aquatic environment at low parts per trillion concentrations , typically at less than $5 \mathrm{ng} / \mathrm{L}$ (Belfroid 1999; Larsson 1999 ; Zhou 2007). WWTP effluents contain mixtures of individual estrogens and their mimics that differ in their ability to elicit estrogenic responses (Thorpe KL 2003). Combinations of estrogenic compounds are present in municipal WWTP effluents but the natural estrogens, E1 and E2, and the synthetic E2 derivate EE2 are most responsible for in vitro estrogenic activity. Each xenoestrogen exhibits its own wildlife or human health risk, but synergistic effects could occur with xenoestrogen mixtures. Wildlife species are rarely exposed to single chemicals but instead are exposed to complex, fluctuating mixtures of contaminants that may act in various ways (Thorpe KL 2001; Silva E 2002; Sumpter 2003; Thorpe KL 2003) and that may induce combination effects (Rajapakse, Silva et al. 2002) via the same or different mechanisms. Less than 1 $\mathrm{ng} / \mathrm{L}$ EE2 can cause feminization of male fishes, $4 \mathrm{ng} / \mathrm{L}$ caused abnormal reproductive development in male fathead minnows. E2 has been detected at concentrations from $1 \mathrm{ng} / \mathrm{L}$ to $80 \mathrm{ng} / \mathrm{L}$ in surface water. Total estrogenicity (E2 equivalents) of $147 \mathrm{ng} / \mathrm{L}$ and $17 \mathrm{ng} / \mathrm{L}$ has been measured in final WWTP effluent and surface water respectively. NP and brominated biphenyls, a flame retardant have been detected between 0.1-3.7 $\mu \mathrm{g} / \mathrm{L}$ and $0.3-4.6 \mathrm{mg} / \mathrm{kg}$ (on suspended particles) respectively and at $6-135 \mathrm{ng} / \mathrm{L}$ in river water and 2-15 ng/L in drinking water (Kuch and Ballschmiter 2001). Diethyl hexyl phthalate has been detected in sewage sludge between 15-50 ng/g (Petrovic and Barcelo 2000) and at 5-10 ng/L in surface and drinking water (Hyötyläinen 1997). Di butyl phthalate has been reported at a concentration of 5-10 $\mathrm{ng} / \mathrm{L}$ in surface water and drinking water (Hyötyläinen 1997). Bisphenol A concentrations have been reported in drinking water from $300 \mathrm{pg} / \mathrm{L}$ to $2 \mathrm{ng} / \mathrm{L}$ and in river water from $500 \mathrm{pg} / \mathrm{L}$ up to $16 \mathrm{ng} / \mathrm{L}$ (Kuch and Ballschmiter 2001).

\section{CONCLUSION}

Understanding the species and concentrations of pharmaceutical and xenoestrogen in WWTP effluent, septic leachate, groundwater and surface water is imperative for environmental public health tracking of associated disease states. The current environmental concentrations of both pharmaceutical and xenoestrogens seem to be adequate to cause harmful health effects for human and wildlife and thus, human exposure to these compounds is a very valid public health concern.

Further research is needed to determine specific associations between disease states and pharmaceutical estrogen and or xenoestrogen exposure. Through the Toxic Substance Control Act (TSCA) the USEPA provides a very limited and inadequate framework to evaluate the estrogenic potential of new and existing chemical substances, intermediates and products. The TSCA program does this, as do all modern chemical evaluation programs, by evaluating each chemical singly. It does not allow for testing the natural combinations of environmentally relevant concentrations of pharmaceutical and xenoestrogens and resulting synergies that may take place. Through modification of the CWA 
discharges such as WWTP effluents must be regulated due to their estrogenic potential. Additionally, through the SDWA the concentrations and number of potential estrogenic compounds present in our drinking water can be regulated. Most studies that have quantitatively measured pharmaceutical estrogens or xenoestrogens in WWTP effluents or surface water use a detection limit (DL) of $0.02 \mathrm{ng} / \mathrm{L}$ thus concentrations below this level are not measured. Yet, it is evident from the physical and reproductive malformations of fishes in these waters that there are possible health effects from concentrations below these DLs. Thus, quantitative methodologies must be established that can measure both xenoestrogen and pharmaceutical estrogenic concentration well below these levels. Estrogenic assays such as proliferation of MCF-7 human breast cancer cells (an estrogen receptor positive cell line), can be used to evaluate combined chemical estrogenicity. Naturalistic wildlife and holistic ecosystem effects studies also provide valuable risk information concerning cumulative estrogenicity at the level of a system or population, but these studies are few. Additionally, an important aspect of the total risk to humans and the environment from ingestion of xenoestrogens is the profusion of substances with estrogenic activity that are being introduced into water through municipal (household) sources or industrial processes. The EPA must incorporate appropriate methodologies to evaluate total estrogenic and other risk from environmental mixtures of the many commonly found pharmaceutical estrogens and xenoestrogens. We propose that categories of estrogens and their mimics be created for testing purposes that take into account their bioavailability, their probable uses and likely disposal paths. Ecological and other methods must be developed to assess their likely combined impacts on living receptors in the aquatic environment through the use of sentinel species. Such research will determine the necessity for utilizing limited and competing public financial resources to invest in technology to remove pharmaceutical estrogens and xenoestrogens from surface waters and, in regulation of fish or wildlife consumption from our rivers and lakes.

This work is made possible through a grant from the Centers for Disease Control and Prevention's Environmental Public Health Tracking (EPHT) Network to the University of Pittsburgh, Academic Center for Excellence (UPACE) in EPHT. Support was also provided by the Heinz Endowments and the Highmark Foundation through the University of Pittsburgh Cancer Institute, Center for Environmental Oncology.

\section{REFERENCES}

Adlercreutz, H. (1995 ). "Phytoestrogens: Epidemiology and a Possible Role in Cancer Protection " Environment Health Perspective 7(103): 103-112.

Atienzar FA, B. Z., Depledge MH. (2002). "4-n-Nonylphenol and 17-beta estradiol may induce common DNA effects in developing barnacle larvae." Environ Pollut. 3(120): 735-738.

Banerjee SK, B. S., Li SA, Li JJ. (1994). "Induction of chromosome-aberrations in Syrian-hamster renal cortical-cells by various estrogens." Mutat Res Fundam Mol Mech Mutagen. 2(311): 191-197.

Baronti, C., R. Curini, G. D’Ascenzo, A. Di Corcia, A. Gentili, R. Saperi, (2000). "Monitoring Natural and Synthetic Estrogens at Activated Sludge Sewage Treatment Plants and in a Receiving River Water " Environ. Sci. Technol. (34): 5059.

Belfroid, A., Van der Horst, A, Vethaak, AD, Schäfer, AJ, Rijs, GBJ, Wegener, J \& Confino, WP. (1999). Sci Total Environ (225,): 101-108.

Bolz, U., H. Hagenmaier, et al. (2001). "Phenolic xenoestrogens in surface water, sediments, and sewage sludge from Baden-Wurttemberg, south-west Germany." Environ Pollut 115(2): 291-301.

Carlsen, E., Giwercman, A., Keiding, N., and Skakkebaek, N. K. (1995). "Declining semen quality and increasing incidence of testicular cancer: Is there a common cause?" Environ. Health Perspect.(103): 137-139. 
Choi SM, Y. S., Lee BM. (2004). "Toxicological characteristics of endocrine-disrupting chemicals: developmental toxicity, carcinogenicity, and mutagenicity." J Toxicol Environ Health B Crit Rev 1(7): 1-32.

Colborn T, V. S. F., Soto AM. (1993). "Developmental effects of endocrine-disrupting chemicals in wildlife and humans." Environ Health Perspect 101: 378-384.

Crain DA, S. I., Guillette LJ Jr. (1999). "The functional and structural observations of the neonatal reproductive system of alligators exposed in ovo to atrazine, 2,4-D or estradiol." Toxicol Ind Health (15): 180-185.

Daughton, C. G. T., Thomas A (1999). "Pharmaceuticals and Personal Care Products in the Environment:Agents of Subtle Change?" Environ Health Perspect. 107(suppl 6): 907-938.

Desbrow, C. R., E. J.; Brighty, G. C.; Sumpter, J. P.; and M. Waldock (1998). "Identification of estrogenic chemicals in STW effluent. 1. Chemical fractionation and in vitro biological screening." Environ. Sci. Technol. 11(32): 1549-1558.

Feyk LA, G. J. (1998). "Xenobiotic modulation of endocrine function in birds. In: Principles and Processes for Evaluating Endocrine Disruption in Wildlife(Kendall R, Dickerson R, Giesy J, Suk W, eds)." Pensacola, FL:SETAC Press: 121-140.

Gaido KW, L. L., Lovell S, Gould JC, Babai D, Portier CJ, et al. (1997). "Valuation of chemicals with endocrine modulating activity in a yeast-based steroid hormone receptor gene transcription assay. ." Toxicol Appl Pharmacol. 1(143): 205-212.

Giesy JP, L. J., Tillitt DE. (1994). "Deformities of birds in the Great Lakes region: assigning causality. ." Environ Sci Technol 28: 128A-135A.

Giwercman, A., Carlsen, E., Keiding, N., and Skakkebaek, N. E. (1993). "Evidence for increasing incidence of abnormalities of the human testis: A review. ." E Environ. Health Perspect. (101): $65-72$.

Gray LE, O. J., Kelce WR. (1994). "Developmental effects of an environmental antiandrogen: the fungicide vinclozolin alters differentiation of the male rat." Toxicol Appl Pharmacol 129: 46-52.

Guillette LJ Jr, C. D., Rooney AA, Pickford DB. (1995). "Organization versus activation: the role of endocrine-disrupting contaminants (EDCs) during embryonic development in wildlife." Environ Health Perspect 103(suppl 7): 157-164.

Guillette LJ Jr, G. T., Masson GR, Matter JM, Percival HF, Woodward AR. (1994). "Developmental abnormalities of the gonad and abnormal sex hormone concentrations in juvenile alligators from contaminated and control lakes in Florida." Environ Health Perspect 102: 680-688

Guillette LJ Jr, P. D., Crain DA, Rooney AA, Percival HF (1996). "Reduction in penis size and plasma testosterone concentrations in juvenile alligators living in a contaminated environment. ." Gen Comp Endocrinol 101: 32-42.

Han XL, L. J. (1994). "8-Hydroxylation of guanine bases in kidney and liver DNA of hamsters treated with estradiol-role of free radicals in estrogen-induced carcinogenesis." Cancer Res. 21(54): 5515-5517.

Harris CA, S. E., Janbakhsh A, Pottinger TG, Tyler CR, Sumpter JP. (2001). "Nonylphenol affects gonadotropin levels in the pituitary gland and plasma of female rainbow trout." Environ Sci Technol. 14 (35): 2909-2916.

Hayes TB, C. A., Lee M, Mendoza M, Noriega N, Stuart AA, et al. (2002). "Hermaphroditic, demasculinized frogs after exposure to the herbicide atrazine at low ecologically relevant doses." Proc Natl Acad Sci USA (99): 5476-5480.

Hutson Susan S., N. L. B., Joan F. Kenny, Kristin S. Linsey, Deborah S. Lumia, and Molly A. Maupin (2004). Estimated Use of Water in the United States in 2000. . U. S. G. S. U.S. Department of Interior, U.S. Geological Survey. U.S. Geological Survey Circular 1268.

Hyötyläinen, T. K. G., M. Biedermann, M.L. Riekkola, J. (1997). "Reversed phase HPLC coupled on-line to $\mathrm{GC}$ by the vaporizer/precolumn solvent split/gas discharge interface; analysis of phthalates in water." High Resolut. Chromatogr. 20: 410. 
Jin, X. L., G. L. Huang, et al. (2004). "Simultaneous determination of 4-tert-octylphenol, 4-nonylphenol and bisphenol A in Guanting Reservoir using gas chromatography-mass spectrometry with selected ion monitoring." J Environ Sci (China) 16(5): 825-8.

Jobling, S., CR Tyler (2003). "Endocrine Disruption in Wild Freshwater Fish." Pure Appl. Chem 75(1112): 2219-2234.

Jobling S, N. M., Tyler CR, Brighty G, Sumpter JP. (1998). "Widespread sexual disruption in wild fish." Environ Sci Technol. 17(32): 2498-2506.

Kidd, K. A., P. J. Blanchfield, et al. (2007). "Collapse of a fish population after exposure to a synthetic estrogen." Proceedings of the National Academy of Sciences of the United States of America 104(21): 8897-8901.

King, T. E., S. J. Ballereau, et al. (2006). "Genetic signatures of coancestry within surnames." Curr Biol 16(4): 384-8.

Körner, W., Ulrike Bolz, Rita Triebskorn, Julia Schwaiger, Rolf- Dieter Negele, and A. M. a. H. Hagenmaier (2001). "Steroid Analysis and Xenosteroid Potentials in the Small Streams in Southwest Germany " Journal of Aquatic Ecosystem Stress and Recovery(8): 215-229.

Kuch, H. M. and K. Ballschmiter (2001). "Determination of endocrine-disrupting phenolic compounds and estrogens in surface and drinking water by HRGC-(NCI)-MS in the picogram per liter range." Environ Sci Technol 35(15): 3201-6.

Larsson, D., Adolfsson-Erici, M, Parkkonen, J, Pettersson, M, Berg, AH, Olsson, P-E \& Forlin, L. (1999 ). Aquat Toxicol(45): 91-97.

Liney, K. E., J. A. Hagger, et al. (2006). "Health effects in fish of long-term exposure to effluents from wastewater treatment works." Environ Health Perspect 114 Suppl 1: 81-9.

Magliulo L, S. M., Cepriano J, Ling J. (2002). "Endocrine disruption caused by two common pollutants at "acceptable" concentrations." Neurotoxicol Teratol. 1(24): 71-79.

Meyer, V. F. (2001). "The Medicalization of Menopause: Critique and Consequences." International Journal of Health Sciences 4(31): 769-792.

Norris, D. O. (2007). Xenoestrogen Actions on Reproduction: Implications for Health of Wildlife And Humans. American Water Resources Association 2007 SUMMER SPECIALTY CONFERENCE, Emerging Contaminants of Concern in the Environment: Issues, Investigations and Solutions.

Nutter LM, N. E., Abulhajj YJ. J Biol Chem. (1991). "Characterization of DNA damage induced by 3,4estrone-ortho-quinone in human-cells. ." 25(266): 16380-16386.

Nutter LM, W. Y., Ngo EO, Sierra EE, Gutierrez PL, Abulhajj YJ. (1994 ). "An O-quinone form of estrogen produces free radicals in human breast-cancer cells-correlation with DNA-damage. ." Chem Res Toxicol. 1(7): 23-28.

Petrovic, M. and D. Barcelo (2000). "Determination of Anionic and Nonionic Surfactants, Their Degradation Products, and Endocrine-Disrupting Compounds in Sewage Sludge by Liquid Chromatography/Mass Spectrometry." Anal. Chem. 72(19): 4560-4567.

Purdom, C. E. H., P. A.; Bye, V. J.; Eno, N. C.; Tyler, C. R.; Sumpter, J. P. (1994). Chem. Ecol. 8: 275285.

Rajapakse, N., E. Silva, et al. (2002). "Combining xenoestrogens at levels below individual no-observedeffect concentrations dramatically enhances steroid hormone action." Environ Health Perspect 110(9): 917-21.

Routledge, E. J., D. Sheahan, et al. (1998). "Identification of Estrogenic Chemicals in STW Effluent. 2. In Vivo Responses in Trout and Roach." Environ. Sci. Technol. 32(11): 1559-1565.

Safe, S. H. (2000). "Endocrine Disruptors and Human Health-Is There a Problem? An Update." Environmental Health Perspectives 108(6): 487-493.

Sharpe, R. M., J. S. Fisher, et al. (1995). "Gestational and lactational exposure of rats to xenoestrogens results in reduced testicular size and sperm production." Environ Health Perspect 103(12): 113643. 
Silva E, R. N., Kortenkamp A. (2002). "Something from "nothing"-eight weak estrogenic chemicals combined at concentrations below NOECs produce significant mixture effects." Environ Sci Technol. 8(36): 1751-1756.

Sohoni, P., Sumpter, J. P. (1998). "Several environmental oestrogens are also anti-androgens." $\underline{J}$ Endocrinol 158(3): 327-39.

Stachel, B., U. Ehrhorn, et al. (2003). "Xenoestrogens in the River Elbe and its tributaries." Environ Pollut 124(3): 497-507.

Stevens JL, N. G., Stern GA, Tomy GT, Jones KC. (2003). "PAHs, PCBs, PCNs, organochlorine pesticides, synthetic musks, and polychlorinated n-alkanes in UK sewage sludge: survey results and implications." Environ Sci Technol. 3(37): 462-467.

Sumpter, J. (2003). "Endocrine disruption in wildlife: the future?" Pure Appl Chem. 11-12(75): 23552360.

Sumpter, J. P. and S. Jobling (1995). "Vitellogenesis as a biomarker for estrogenic contamination of the aquatic environment." Environ Health Perspect 103 Suppl 7: 173-8.

Ternes, T. A., M. Bonerz, et al. (2007). "Irrigation of treated wastewater in Braunschweig, Germany: an option to remove pharmaceuticals and musk fragrances." Chemosphere 66(5): 894-904.

Ternes, T. A., P. Kreckel, et al. (1999). "Behaviour and occurrence of estrogens in municipal sewage treatment plants -- II. Aerobic batch experiments with activated sludge." The Science of The Total Environment 225(1-2): 91-99.

Thorpe KL, C. R., Hutchinson TH, Scholze M, Brighty G, Sumpter JP, et al. (2003). "Relative potencies and combination effects of steroidal estrogens in fish." Environ Sci Technol. 6(37): 1142-1149.

Thorpe KL, H. T., Hetheridge MJ, Scholze M, Sumpter JP, Tyler CR. (2001). "Assessing the biological potency of binary mixtures of environmental estrogens using vitellogenin induction in juvenile rainbow trout (Oncorhynchus mykiss)." Environ Sci Technol. 12(35): 2476-2481.

Toppari, J., Larsen, J. C., Christiansen, P., Giwercman, A., Grandjean, P., Guillette, L. J., Jr., Jégou, B., Jensen, T. K., Jounnet, P., Keiding, N., et al. (1996). "Male reproductive health and environmental xenoestrogens." Environmental Health Perspectives Supplements 104: 741.

University of Michigan, C. f. S. S. (2005). U.S. Water Supply and Distribution.

USEPA (2001). Removal of Endocrine Disrupting Chemicals in Drinking Water. D. Office of Research and Development Washington, Technology Transfer and Support Division,National Risk Management Research Laboratory, Office of Research and Development, U.S. Environmental Protection Agency, Cincinnati, Ohio 45268.

USEPA (2004). Primer for Municipal Wastewater Treatment Systems. O. o. W. O. o. W. Management. Washington DC.

Willingham, E. C., D. (1999). "Sex reversal effects of environmentally relevant xenobiotic concentrations on the redeared slider turtle, a species with temperature-dependent sex determination. ." Gen Comp Endocrinol. (113): 429-435.

Zhou, J., Liu, R, Wilding, A \& Hibberd, A. (2007). Environ Sci Technol(41): 206-213. 